\title{
A Case of Breast Cancer Who Diagnosed Erythema Nodosum Due to the Chemotherapy Treatment
}

\section{Kemoterapi Tedavisi Sonucu Eritema Nodozum Gelişen Meme Kanseri Tanılı Bir Olgu}

\author{
Erdem Şen ${ }^{1}$, Fatih İnci ${ }^{1}$, Burcu Keleş ${ }^{2}$, Ceyhan Uğurluoğlu ${ }^{2}$, Gonca Kara Gedik ${ }^{3}$, Özlem Ata ${ }^{1}$ \\ ${ }^{1}$ Selçuk Üniversitesi Tıp Fakültesi Tıbbi Onkoloji Bilim Dalı; Konya \\ ${ }^{2}$ Selçuk Üniversitesi Tıp Fakültesi Tıbbi Patoloji Ana Bilim Dalı; Konya \\ ${ }^{3}$ Selçuk Üniversitesi Tıp Fakültesi Nükleer Tıp Ana Bilim Dalı; Konya
}

Dergiye Ulaşma Tarihi: 23.01.2017 Dergiye Kabul Tarihi: 17.04.2017 Doi: 10.5505/aot.2017.30085

\section{ÖZET}

Eritema nodozum (EN) en s1k görülen septal pannikülit tipidir. Genellikle 15-40 yaş arası bayanlarda görülmektedir. Etyolojik faktörler arasında ilaçlar, enfeksiyonlar, tümörler ve inflamatuvar hastalıklar bulunur. Bununla beraber genellikle nedeni bilinmemektedir. EN patogenezi tam olarak anlaşılamamıştır. Lezyonlar en sık bacaklarda yerleşim gösterir. Bunun dışında uyluk ve ön kolda sıklıkla tutulur. Gövde, boyun ve yüz tutulumu nadirdir. Akut ataklarda ateş, yorgunluk, eklem ağrısı, baş ağrısı, öksürük, karın ağrısı, bulantı veya ishal görülebilir. Enfeksiyonların, bağ doku hastalıklarının veya inflamatuar hastalıkların erken bulgusu olarak karşımıza çıkabilir. Biz meme kanseri tanılı, adjuvan tedavisi için siklofosfamid- doksorubisin- fluorourasil (CAF) kemoterapi tedavisi uygulanan hastada tedaviye bağlı gelişen eritema nodozumun takip ve tedavi sürecini sunmayı amaçladık.

Anahtar Kelimeler: Eritema Nodozum; Meme neoplazm1; Kemoterapi

\begin{abstract}
Erythema nodosum (EN) is the most common type of septal panniculitis. It is usually seen in 15-40 years old females. Etiologic factors include medications, infections, tumors and inflammatory diseases. However, EN generally seen idiopathic. The pathogenesis is poorly understood. Lesions are most often located in the leg. Other than that commonly maintained in the thigh and forearm. Body, neck and facial involvement is rare. Fever, fatigue, arthralgia, headache, cough, abdominal pain, nausea or diarrhea may be occur in the acute attack. EN can appear as early signs of Infections, inflammatory or connective tissue diseases. We wanted to provide the growing EN due to chemotherapy treatment who diagnosed breast cancer and received adjuvant cyclophosfamide-doxorubicin-fluorouracil (CAF) chemotherapy treatment.
\end{abstract}

Key Words: Erythema Nodosum; breast cancer; chemotherapy

\section{Giriş}

Eritema nodozum (EN) septal pannikulitlerin prototipidir. Genellikle pretibial bölgede lokalize olan, kırmızı veya mor ciltaltı nodüller şeklinde karşımıza çıkan inflamatuar nodüllerdir. Değişik antijenik uyaranlara (enfeksiyöz ajanlar, ilaçlar ve diğer hastalıklar) karşı gecikmiş hipersensitivite cevabı olduğu kabul edilmektedir. İnsidans1 1-5/100.000'dir. Genellikle 15-40 yaş arası bayanlarda görülmektedir (1). Klinik olarak pretibial alanlarda yerleşen kırmızı ve sıcak, basmakla ağr1lı, bilateral hassas nodullerle karakterizedir. 3-6 hafta sonunda ülserleşme olmadan, skar bırakmadan kendiliğinden iyileşirler. Etiyolojide enfeksiyonlar, ilaçlar, maligniteler, sistemik inflamatuvar hastalıklar ve gebeliğin olduğu oldukça geniş bir spektrum vardir. Bununla beraber genellikle idiopatik görülmektedir. Enfeksiyonların, bağ doku hastalıklarının veya inflamatuar hastalıkların erken bulgusu olarak karşımıza çıkabilir (2).

Biz bu çalışmamızda meme kanseri tanısı almış, opere olmuş, uzak organ metastazı bulunmayan, adjuvan kemoterapi tedavisi devam ederken ilaca bağlı EN gelişen bir olgumuzu sunmaya çalıştık. 


\section{Olgu}

Kırk iki yaşında bayan hasta yaklaşık olarak 1 aydır sol memede kitle nedeni ile genel cerrahi bölümüne başvurdu. Sol memedeki kitleden yapılan biyopsi sonucunun patolojik incelemesinde invaziv duktal karsinom (Grade 3, cerb b2 (+++), ER (+), PR (-)) tanisı konuldu. Daha sonrasinda hastaya sol modifiye radikal mastektomi operasyonu yapıldı. Bölümümüze post operatif dönemde başvuran hastanın evreleme amaçlı çekilen pozitron emisyon tomografi-bilgisayarlı tomografi (PET-BT) tetkikinde sol infraklaviküler bölgede $8 \mathrm{~mm}$ lenfadenopati (LAP) (SUVmax:6.7) saptand. Hasta evre III C meme malign neoplazmı olarak kabul edildi. Hastaya adjuvan tedavi amaci ile ilk aşamada CAF kemoterapisi tedavisi verilmesi planlandı ve başland1. İlk 2 kür kemoterapi tedavisi sirasinda veya sonrasında herhangi bir yakınması olmayan hastada 3. kür verildikten yaklaşık 1 hafta sonra kaşıntı, kalçalarda, uylukta, sol meme insizyon yerinde cilt altında ele gelen, üzeri basmakla hassas, sıcaklık artışının eşlik ettiği nodüler lezyonlar saptandı. Hastanın kontrol amaçlı çekilen PETBT tetkikinde sol meme cilt altında en büyüğü $2,5 \mathrm{~cm}$ boyutunda (SUV max:9.11), sağ ve sol gluteal bölgede cilt altında en büyüğü $2,5 \mathrm{~cm}$ çaplı (SUV max:9.58) nodüler lezyonlar saptand1 (Figür 1).

Lokal ve sistemik nüks açısından şüphelenilen hastanın PET-BT' deki saptanan sol meme ve gluteal bölgedeki lezyonlarından biyopsiler alındı. Lezyonların patolojik incelemesi sonucu maligniteye ait bulgu saptanmad. Lezyonlar eritema nodozum ile uyumlu olarak raporlandı (Figür 2,3). Kemoterapi tedavisine bağlı EN olarak düşünülen hastanın biyopsi işlemleri ve sonucunun elde edilmesine yönelik süreçte kemoterapi tedavisi kesildi, sonrasında hastanın lezyonları skar birakmadan tamamen geriledi. Yapılan klinik ve laboratuar değerlendirilmesinde altta yatan sistemik bağ doku hastalığını, granülomatöz bir hastalığı, enfeksiyöz bir süreci düşündürecek bir patoloji saptanmad1 (Romatoid faktör, hepatit belirteçleri, anti nükleer antikor negatif, Creactive protein ve eritrosit sedimentasyon hiz1 normal saptand1). İlaç kullanım öyküsünde yeni bir ilaç kullanımı olmadığı öğrenildi. Hastaya daha sonrasında adjuvan haftalık paklitaksel kemoterapi tedavisi ve trastuzumab tedavileri verildi. Adjuvan trastuzumab tedavisi bir y1la tamamland. Kontrollerinde herhangi bir anormallik saptanmadi. Hasta halen adjuvan hormonal tedavisini aliyor. Hastada yeniden ortaya çıkan, aynı karakterde bir cilt lezyonu görülmedi. Takipleri halen sorunsuz olarak devam etmektedir.

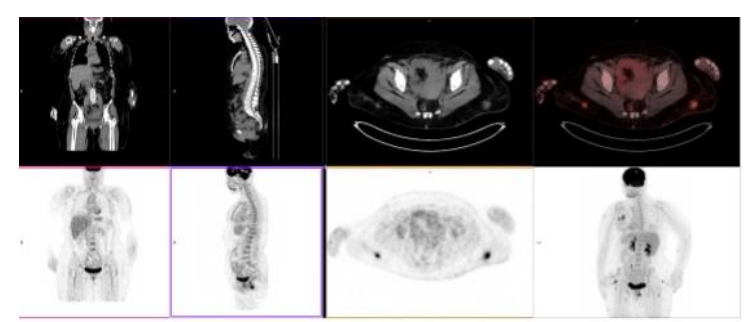

Figür 1: PET-CT (3. kür CAF kemoterapi tedavisi sonras1)

Sağ ve sol gluteal bölgede cilt altında en büyüğü 2,5 cm çapa ulaşan ve artmış FDG tutulumu gösteren multipl nodüler lezyonlar (SUVmax: 9,58). Sağ ve sol ekstremitenin kesit alanına giren bölgelerinde ciltte nodüler kalınlaşmalar ve artmış FDG tutulumu gösteren multipl odaklar

Sol meme cilt altında en büyüğü $2,5 \mathrm{~cm}$ çapında olmak üzere artmış FDG tutulumu gösteren birkaç adet yumuşak doku lezyonu (SUVmax: 9,11).

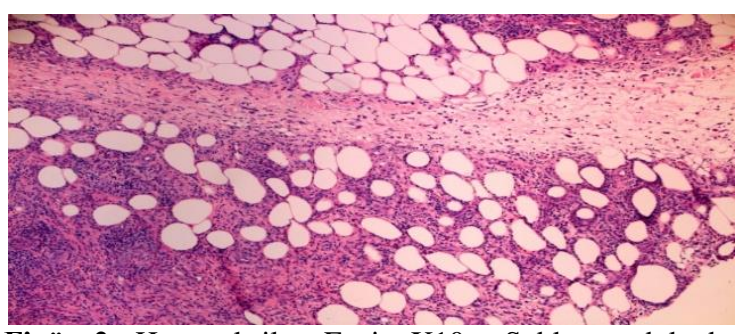

Figür 2: Hematoksilen Eosin X10 : Subkutan dokuda eozinofilleri ve histiositleri de içeren iltihabi hücre infiltrasyonu ile karakterize septal pannikülit

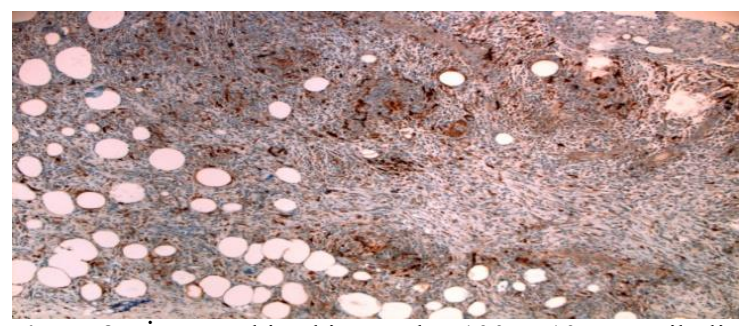

Figür 3: İmmünohistokimyasal S100 X10: Pannikülit alanında histiositler

\section{Tartışma}


Eritema nodozum (EN) çeşitli uyaranların tetiklediği reaktif bir süreç olup klinik olarak en sık görülen septal pannikülittir. Vakaların $\% 55$ 'i idiopatik olup en sik nedenler enfeksiyonlar (streptokok, tüberküloz, yersiniyozis, üst solunum yolu enfeksiyonları), ilaçlar (oral kontraseptifler, penisilin, sülfonamidler), sarkoidoz, İnflamatuar bağırsak hastalıklarından (IBH), gebelik ve Hodgkin lenfoma gibi malignitelerdir (3). EN patogenezi tam olarak anlaşılamamıştır, ancak subkutan yağ dokusu septumlarının venüllerinde immün komplekslerin birikimi sonucu olduğu düşünülmektedir (4). Hastalığın etyopatogenezinde antijene yanıt olarak gelişen immün aracılı mekanizmalar özellikle de gecikmiş tip hipersensitivite reaksiyonları suçlanmaktadır (5). EN' da klasik histopatolojik bulgu vaskülitsiz akut septal pannikülitdir. Septumda erken bulgu nötrofilik infiltrasyon, geç bulgusu ise lenfohistiyositer hücrelerin baskın olduğu ve histiyositik dev hücreleri içeren Miescher' in mikrogranülomatöz odağıdır (6).

Ani başlayan, simetrik, hassas, eritemli, sıcak nodül ve plaklar karakteristiktir. Lezyonlar en sik bacaklarda yerleşim gösterir. Bunun dişında uyluk ve önkollarda sıklıkla tutulur. Gövde, boyun ve yüz tutulumu nadirdir. Diğer pannikülitlerden farklı olarak ülserasyon görülmez. Akut ataklarda ateş, yorgunluk, atralji, başağrısı, öksürük, karın ağrısı, bulantı veya diyare görülebilir. Episkleral lezyonlar ve konjonktivit eşlik edebilir (7).

EN ve malignite birlikteliği incelendiğinde sıklıkla lenfomalarla olan ilişki öne çıkmaktadır. Bununla birlikte hepatosellüler karsinom, akciğer kanseri, paratiroid karsinomu, pankreas kanseri, karsinoid tümör, meme kanseri gibi malignitelerde tanı sırasında EN geliştiği rapor edilmiştir (8-11).

Literatür incelendiğinde CAF kombinasyon kemoterapi rejimi ile tedavi surasinda veya sonrasında kaşıntı, ürtiker, döküntü, fotosensitivite, pigmentasyonda artış, el ayak deri sendromu, dermatit, cilt kuruluğu, erythema multiforme, Stevens-Johnson sendromu, toksik epidermal nekrolizis gibi cilt toksisiteleri görülebildiği bildirilmiştir. CAF kombinasyon kemoterapi rejimine bağlı cilt toksisiteleri araştıııldığında veya içerisindeki kemoterapotik ajanlara bağlı cilt toksisiteleri tek tek incelendiğinde Eritema nodozuma yol açabildikleri gösterilememiştir.

Adjuvan kemoterapi tedavisi kesilip izleme alınan olgumuzdaki lezyonların kendiliğinden kaybolması, tekrarlanan tedavi rejiminin son küründe böyle bir durumun ortaya çıkması, hastada tümör varlığına yönelik kanıt bulunmaması, Eritema nodosuma yol açabilecek başka bir hastalık bulgusu saptanmaması nedenleri ile hastada gelişen Eritema nodozumun CAF kemoterapi tedavisine bağlı olarak geliştiği düşünülmüştür. $\mathrm{Bu}$ durum kemoterapi rejiminde bulunan herhangi bir ilaca bağlı gelişmiş olabileceği gibi ilaçların kombinasyonu ile etkileşim sonucunda da gelişmiş olabilir. Kombinasyon rejiminde bulunan ilaçların hangisinin EN gelişimi açısından yüksek riskli olduğuna dair bir veri bulunmamaktadır. Kemoterapi tedavisi uygulanan hastalarda alerjik reaksiyonlar olmaması amacı ile tedavi öncesi antihistaminik, steroid, $\mathrm{H}_{2}$ reseptör blokörü gibi ilaçlar verilmektedir. Bu ilaçlar her kemoterapi rejiminden önce uygulanmaktadır. Olgumuzda EN gelişiminden bu premedikasyondaki ajanlar sorumlu olsayd, her premedikasyon uygulaması ile sonradan da EN gelişmesi beklenebilirdi.

\section{Çıkar çatışması: Yok}

\section{Kaynaklar}

1. González-Gay MA, García-Porrúa C, Pujol RM, Salvarani C. Erythema nodosum: a clinical approach. Clin Exp Rheumatol 2001;19(4):365-8

2. Mana J, Marcoval J. Erythema nodosum. Clin Dermatol 2007;25(3):288-94

3. Blake T, Manahan M, Rodins K. Erythema nodosum -a review of an uncommon panniculitis. Dermatol Online J 2014;16;20(4) :22376

4. Hannuksela M. Erythema nodosum. Clin Dermatol 1986;4(4):88-95

5. Schwartz RA, Nervi SJ: Erythema nodosum: a sign of systemic disease. Am Fam Physician 2007;75(5):695-700

6. Soderstrom RM, Krull EA. Erythema nodosum. A review. Cutis 1978;21(6): :806-10

7. Requena L, Yus ES. Panniculitis. Part I. Mostly septal panniculitis. J Am Acad Dermatol 2001;45(2):163183;quiz 184-6

8. Glinkov S, Krasnaliev I, Atanassova M, Arnaudov P, Kirov K, Glinkova V. Hepatocellular carcinoma associated with paraneoplastic erythema nodosum and polyarthritis. J Hepatol 2003;39(4):656-7

9. Durden FM, Variyam E, Chren MM. Fat necrosis with features of erythema nodosum in a patient with metastatic pancreatic carcinoma. Int $\mathbf{J}$ Dermatol 1996;35(1):39-41

10. Bonci A, Di Lernia V, Merli F, Lo Sococco G. Erythema nodosum and Hodgkin's disease. Clin Exp Dermatol 2001;26(5):408-11

11. Lin JT, Chen PM, Huang DF, Kwang WK, Lo K, Wang WS. Erythema nodosum associated with carcinoid tumor. Clin Exp Dermatol 2004;29(4):4267 